\title{
From Planning to Action: Implementation of State Climate Change Adaptation Plans
}

\author{
AARON D. RAY ${ }^{1 *}$ AND JESSICA GRANNIS ${ }^{1}$ \\ Volume 3, Spring 2015 \\ http://dx.doi.org/10.3998/mjs.12333712.0003.001 \\ ${ }^{1}$ Georgetown Climate Center, Georgetown University Law Center, 600 New Jersey Ave, \\ NW, Washington, DC 20001 \\ *Corresponding Author: Aaron Ray, ray@ law.georgetown.edu
}

\section{ABSTRACT}

States are using climate change adaptation plans to prepare for the impacts of climate change. As of October 2014, 14 states had finalized state-led adaptation plans. An additional eight states and the District of Columbia had some adaptation planning underway. The Georgetown Climate Center is tracking implementation of these plans and making these data available to scholars, practitioners, and the public through an interactive tool in the Climate Center's Adaptation Clearinghouse. This research provides, for the first time, an empirical assessment of the progress that states are making implementing their adaptation plans. Among states with plans, there is significant variation in the number of goals included in each plan, the sectors covered, and the degree of implementation that has occurred. The number of discrete goals in state plans ranges from 28 to 373, and the level of implementation progress ranges from 16 to $87 \%$. Our research demonstrates that states are actively implementing the goals in their adaptation plans, but the process of plan development and the progress in implementation are highly state specific.

\section{Introduction}

The impacts of climate change are now challenging and will continue to challenge public institutions at all levels of government. Proactive climate adaptation involves adjustments in human systems that moderate the harm of or exploit beneficial op- 
portunities related to actual or expected climate impacts (IPCC 2007). Federal agencies, state and local governments, private actors, and non-governmental organizations may undertake such proactive planning, which we refer to as adaptation. Our research focuses on the actions of state governments in the United States. While planning at the state level is not sufficient to adequately prepare for climate impacts, state action is a necessary component of a national response to climate change. Indeed, scholars have predicted and observed state leadership on climate change policy (Rabe 2004; Selin and VanDeveer 2007; Thomson and Arroyo 2011; Arroyo and Cruce 2012).

A number of states have been early actors in developing and implementing climate change adaptation plans. As of October 2014, 14 states $^{1}$ had finalized state-led adaptation plans. An additional eight states and the District of Columbia ${ }^{2}$ had some adaptation planning underway (see Map 1). ${ }^{3}$ These plans reflect the effort of states to proactively adapt to the current and future impacts of climate change. After states have adopted plans, they face the challenge of implementing them. Although some research has analyzed the development of these state plans (Wheeler 2008; Arroyo and Cruce 2012), until recently, state officials, scholars, practitioners, and the public lacked a quantifiable, cross-state assessment of the progress states are making in implementing their adaptation plans. Without these data, we have been unable to determine what progress states are making in preparing for climate impacts. The research we describe here is an early attempt to address that question.

Our research has found that that there is significant variation among states across multiple dimensions. ${ }^{4}$ This variation can be seen 1 ) in the process states undertook to develop their plans, 2) in the content of those plans, and 3) in the progress states are making in implementing their plans. States are actively implementing the goals in their adaptation plans, but the process of plan development, the content of plans, and the progress of implementation is highly state specific. In addition to identifying the variation that has characterized this first round of state adaptation planning, it is possible to propose a number of potential factors that influence this variation. These include the impetus for the plan (e.g., by executive order or legislative mandate), the number of recommendations in the plan, the level of political support,

1. Alaska, California, Colorado, Connecticut, Florida, Maine, Maryland, Massachusetts, New Hampshire, New York, Oregon, Pennsylvania, Virginia, and Washington.

2. District of Columbia, Delaware, Hawaii, Michigan, Minnesota, New Jersey, Rhode Island, Vermont, and Wisconsin.

3. All data are available from the Georgetown Climate Center. See http://www.georgetownclimate.org/adaptation/stateand-local-plans

4. A full description of our methodology is included in Appendix II and is available at http://www.georgetownclimate. org/node/9562 


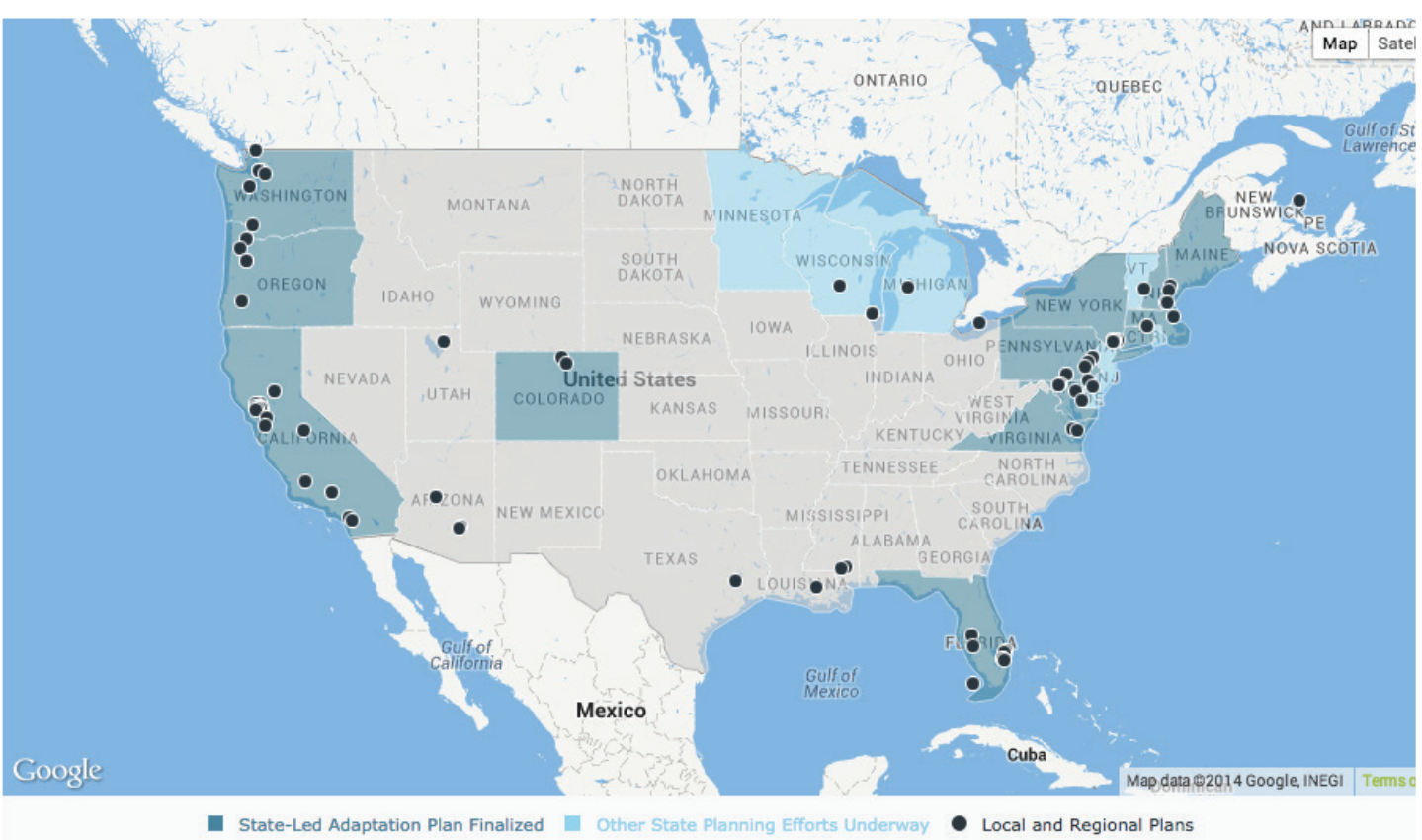

Map 1. State and local adaptation planning in the United States.

and the time elapsed since the publication of the plan. Our research suggests some factors that may influence the progress states are making in implementing their plans. We leave it to other scholars and future work to formally test the influence of these factors. The primary aim of this research is to assess the level of progress states are making in implementing their adaptation plans.

\section{Plan development}

There is considerable variation in the process by which states initiated, developed, and adopted adaptation plans (see Table 1). The 14 states with state-led, finalized adaptation plans initiated the development of these plans between 2007 and 2009. Nine of these states initiated the process through executive action, while the remaining five initiated the process through legislative action. The resulting plans were finalized between 2008 and 2013. The average time from initiation of the process to completion of a plan was just over two years. State agencies most often led the development of the plans, with academic and non-governmental organization participation. We did not examine the particular political dynamics driving plan 
TABLE 1. State climate change adaptation plans.

\begin{tabular}{|c|c|c|c|c|c|}
\hline State & Initiated & Executive action & Legislative action & Plan & Finalized \\
\hline Alaska & 2007 & $\begin{array}{l}\text { Administrative Order } \\
238 \text { (Palin) }\end{array}$ & & $\begin{array}{l}\text { Alaska Climate Change } \\
\text { Strategy: Addressing Impacts } \\
\text { in Alaska }\end{array}$ & 2010 \\
\hline California & 2008 & $\begin{array}{l}\text { Executive Order S-13-08 } \\
\text { (Schwarzenegger) }\end{array}$ & & $\begin{array}{l}\text { California Climate } \\
\text { Adaptation Strategy }\end{array}$ & 2009 \\
\hline Colorado & 2008 & $\begin{array}{l}\text { Executive Order B007-08 } \\
\text { (Ritter) }\end{array}$ & & $\begin{array}{l}\text { Final Report of the Colorado } \\
\text { Climate Preparedness Project }\end{array}$ & 2011 \\
\hline Connecticut & 2008 & & $\begin{array}{l}\text { Public Act No. 08-98: An } \\
\text { Act Concerning Connecticut } \\
\text { Global Warming Solutions }\end{array}$ & $\begin{array}{l}\text { Connecticut Climate } \\
\text { Change Preparedness Plan }\end{array}$ & 2013 \\
\hline Florida & 2007 & $\begin{array}{l}\text { Executive Order 07-128 } \\
\text { (Crist) }\end{array}$ & & $\begin{array}{l}\text { Florida's Energy and Climate } \\
\text { Change Action Plan }\end{array}$ & 2008 \\
\hline Maine & 2009 & & $\begin{array}{l}\text { LD 460/SPO 163: Resolve, } \\
\text { To Evaluate Climate Change } \\
\text { Adaptation Options for the } \\
\text { State }\end{array}$ & $\begin{array}{l}\text { People and Nature Adapting } \\
\text { to Climate Change: } \\
\text { Charting Maine's Course }\end{array}$ & 2010 \\
\hline Maryland & 2007 & $\begin{array}{l}\text { Executive Order } \\
01.01 .2007 .07 \\
\text { (O’Malley) }\end{array}$ & & $\begin{array}{l}\text { Comprehensive Strategy } \\
\text { for Reducing Maryland's } \\
\text { Vulnerability to Climate } \\
\text { Change: Phase I: Sea-level } \\
\text { rise and coastal storms } \\
\text { Phase II: Building societal, } \\
\text { economic, and ecological } \\
\text { resilience }\end{array}$ & 2008 \\
\hline Massachusetts & 2008 & & $\begin{array}{l}\text { S 2540: Global Warming } \\
\text { Solutions Act of } 2008\end{array}$ & $\begin{array}{l}\text { Massachusetts Climate } \\
\text { Change Adaptation Plan }\end{array}$ & 2011 \\
\hline New Hampshire & 2007 & $\begin{array}{l}\text { Executive Order Number } \\
\text { 2007-3 (Lynch) }\end{array}$ & & $\begin{array}{l}\text { New Hampshire Climate } \\
\text { Action Plan: A Plan for } \\
\text { NH's Energy, Environment, } \\
\text { and Economic Development } \\
\text { Future }\end{array}$ & 2009 \\
\hline New York & 2009 & $\begin{array}{l}\text { Executive Order } 24 \\
\text { (Paterson) }\end{array}$ & & $\begin{array}{l}\text { New York State Climate } \\
\text { Action Plan }\end{array}$ & 2010 \\
\hline Oregon & 2009 & $\begin{array}{l}\text { Governor directs state } \\
\text { agencies and partners } \\
\text { to develop adaptation } \\
\text { recommendations } \\
\text { (Kulongoski) }\end{array}$ & & $\begin{array}{l}\text { Oregon Climate Change } \\
\text { Adaptation Framework }\end{array}$ & 2010 \\
\hline Pennsylvania & 2008 & & $\begin{array}{l}\text { Act 70: The Pennsylvania } \\
\text { Climate Change Act }\end{array}$ & $\begin{array}{l}\text { Pennsylvania Climate } \\
\text { Adaptation Planning Report: } \\
\text { Risks and Recommendations }\end{array}$ & 2011 \\
\hline Virginia & 2007 & $\begin{array}{l}\text { Executive Order } 59 \\
\text { (Kaine) }\end{array}$ & & $\begin{array}{l}\text { Virginia's Final Report: A } \\
\text { Climate Change Action Plan }\end{array}$ & 2008 \\
\hline Washington & 2009 & & $\begin{array}{l}\text { E2SSB 5560: State Agency } \\
\text { Climate Leadership Act }\end{array}$ & $\begin{array}{l}\text { Preparing for a Changing } \\
\text { Climate: Washington State's } \\
\text { Integrated Response Strategy }\end{array}$ & 2012 \\
\hline
\end{tabular}


development and adoption in each state. We leave it to other scholars to more fully characterize the process of plan development in each individual state, particularly with regard to the influence of political dynamics and the role of non-state actors.

The process Washington State used is representative of states whose planning was initiated by legislative action. In 2009, the Washington state legislature enacted a statute requiring state agencies to develop an integrated climate change response strategy (E2SSB 5560: State Agency Climate Leadership Act). The Department of Ecology was tasked with leading the development of this strategy. State agencies were supported by academic and non-governmental organizations including the Climate Impacts Group at the University of Washington. In April 2012, the Department of Ecology released the final adaptation plan, Preparing for a Changing Climate: Washington State's Integrated Climate Response Strategy.

Colorado's planning process highlights the important role that academic and non-governmental organizations often play in the development of state adaptation plans. In 2008, Governor Ritter created the state's Climate Change Advisory Panel by executive order (Executive Order B007 08). The Governor also initiated the Colorado Climate Preparedness Project, which was carried out by the Western Water Assessment (WWA), an applied research program based at the University of Colorado, Boulder. Guided by a team of representatives from the Governor's Energy Office, the Colorado Water Conservation Board, and a number of state agencies, the WWA released the "Colorado Climate Preparedness Project: Final Report" in 2011. While some stakeholders do not consider the 2011 document a final adaptation plan for Colorado, the state is pursuing implementation of many of its recommendations.

Like Colorado's planning process, Maryland's was initiated by executive action. On April 20, 2007, Governor O'Malley signed an executive order establishing the Maryland Commission on Climate Change and directing the Commission to create a Climate Action Plan that would include measures to reduce greenhouse gas emissions and prepare for the impacts of climate change (Executive Order 01.01.2007.07). The executive order called for the creation of an Adaptation and Response Working Group within the Commission to develop the adaptation portions of the state's Climate Action Plan. Maryland's focus on both reducing greenhouse gas emissions and preparing for climate impacts reflects a similar dynamic in many states. In a number of cases, including Connecticut, Florida, and others, adaptation planning was integrated into broader climate change planning processes that focused on efforts to reduce greenhouse gas emissions.

Maryland's process was unusual in that the state pursued adaptation planning 
in two phases. The first phase of planning produced a report titled "Comprehensive Strategy for Reducing Maryland's Vulnerability to Climate Change, Phase I: Sealevel Rise and Coastal Storms," which was published on September 12, 2008. The second phase of planning produced a second report titled "Comprehensive Strategy for Reducing Maryland's Vulnerability to Climate Change, Phase II: Building societal, economic, and ecological resilience," which was published on January 24, 2011. In November 2014, Governor O'Malley signed a new executive order expanding the membership and mission of the Maryland Commission on Climate Change (Executive Order 01.01.2014.14).

Maryland is not alone in developing multiple plans, however. The California Natural Resources Agency (CNRA), responding to Executive Order S-13-08, released a comprehensive statewide "Climate Adaptation Strategy" in December 2009. In July 2014, CNRA released an update to the 2009 plan titled "Safeguarding California: Reducing Climate Risk: An update to the California Climate Adaptation Strategy." The 2014 update highlights California's progress in implementing the 2009 plan and includes new and refined adaptation goals for the state. ${ }^{5}$

The variation in the process by which states developed adaptation plans may be a result of each state's particular set of political factors, governmental and nongovernmental capacity, and climate vulnerabilities. A study of adaptation planning in Europe found that nation-states susceptible to extreme weather events and cognizant of the economic costs of inaction were driven to adopt national adaptation strategies (Swart et al. 2009). It may be the case that vulnerability to climate impacts similarly influences states to adopt adaptation plans. While a detailed investigation of this question is beyond the scope of this article, Maryland's 2008 plan acknowledges that the state's coast is particularly vulnerable to storms and that these hazards are "exacerbated by climate change and sea-level rise." The 2008 plan then focuses specifically on steps to reduce this vulnerability.

\section{Plan content}

There is also variation in the content of state adaptation plans. At the most basic level, state adaptation plans vary in the number of goals they include (see Table 2). ${ }^{6}$ The number of goals in each plan ranges from 20 in Maryland's Phase I plan

5. California's 2014 plan is not included in this analysis of state plan implementation. The Climate Center intends to assess implementation of that plan in future phases of our research.

6 . We use the term "goals" to refer to discrete adaptation objectives articulated in each state plan. States use a variety of 


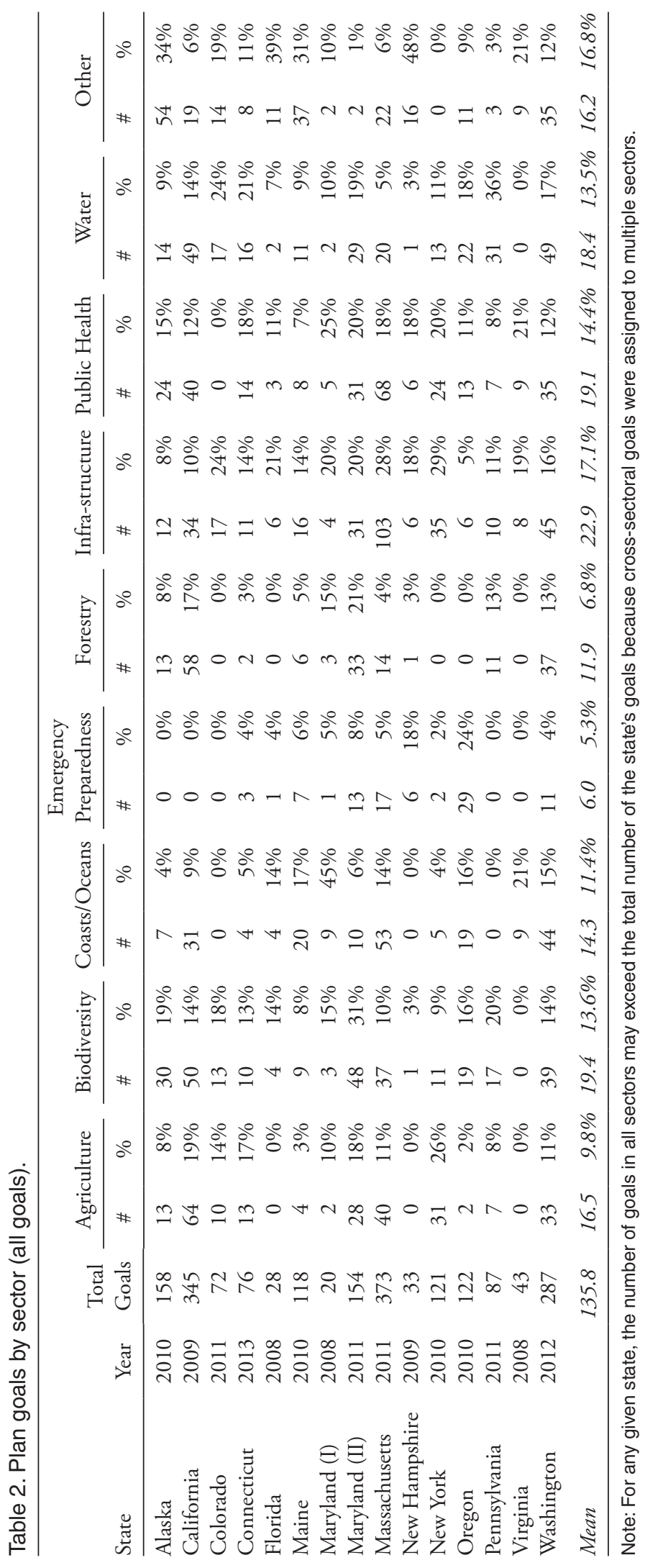


to 373 in Massachusetts' plan. The average number of goals in the plans is 136 . This variation in the number of goals can be interpreted in a number of ways. State agency staff in Washington said their process focused on articulating an ambitious vision for preparing the state for climate impacts, resulting in a plan with 287 goals. These goals address all nine sectors tracked by the Georgetown Climate Center. Other states created plans with a more specific focus. For example, Colorado's plan, which has 72 goals, includes goals in five of the nine sectors. The plans also differ in the specificity of their goals. For example, New York's plan, which has 121 goals, identifies very specific objectives like the need for a new water withdrawal regulation. Florida's plan, which has 28 goals, includes more general objectives like the "Protection of Ecosystems and Biodiversity." This difference in specificity is another example of the idiosyncratic character of each state's approach.

States also vary in the sectors addressed by their plans. We identified nine sectors by which to categorize recommendations in each plan (i.e., Agriculture, Biodiversity, Coasts/Oceans, Emergency Preparedness, Forestry, Infrastructure, Public Health, Water, and Other). ${ }^{7}$ These sectors were applied uniformly across plans to allow for comparison across plans. The sector with the most goals was Infrastructure. On average, $17.1 \%$ of goals were related to Infrastructure. Conversely, the sector with the fewest goals across the plans was Emergency Preparedness. On average, only $5.3 \%$ of goals were related to Emergency Preparedness. The sectors covered by each state's plan may reflect the vulnerabilities of most concern in a given state. For example, three states with little or no coastline (Colorado, New Hampshire, and Pennsylvania) do not include goals related to Coasts and Oceans. Conversely, Maryland's Phase I plan, which focused specifically on the impacts of sea-level rise and coastal storms, devoted $45 \%$ of its goals to the Coasts and Oceans sector. However, other factors may influence the sectors covered in each plan.

There is also variation in the number of recommendations by type. In order to distinguish between the kinds of action called for in each goal, we divided goals into three categories. The Planning and Capacity Building category includes goals that call for the provision of information, express aspirations, encourage collaboration, provide technical assistance, assess vulnerability, recommend additional planning,

terms (e.g., recommendations, strategies, actions, goals) to refer to the objectives in their plans. Our use of the term "goal" allows for a consistent descriptor across plans but admittedly obscures the nuanced meanings of the various terms used by each state.

7. In many cases, these nine sectors do not perfectly match the sectoral categories used by the states in their plans. We chose to use these sectors to enable consistent comparison across states. When our sectors did not match the sectors used by states, we assigned state goals to the most comparable sectoral category. Goals that cross sectors were assigned to multiple sectors. Thus, for any given state, the number of goals in all sectors may exceed the total number of that state's goals. 
etc. For example, Pennsylvania's plan includes the following goal: "Conduct predictive modeling and risk assessment for invasive species and pathogens that may be moving into the state." The Law and Policy category includes goals that create new laws or change existing ones; create new programs; provide new, additional, or redirected funding; reform existing regulations or create new ones, etc. For example, Pennsylvania's plan includes the following goal: "Revise storm water regulations to accommodate increases in precipitation and run-off." Finally, the PostImplementation Monitoring category captures activities that monitor the impact of adaptation actions after they have been implemented. For example, Pennsylvania's plan calls for "More intense inspection of transportation infrastructure after high impact events in areas that are subject to erosion."

Our research found a clear emphasis on planning and capacity building in all plans (see Table 3). The average percentage of goals oriented toward planning and capacity building across all plans was $73 \%$; the percentages ranged from a low of $46 \%$ in Pennsylvania's plan to a high of $93 \%$ in Colorado's plan. Pennsylvania’s plan had the highest number of goals focused on changes to law and policy, with 53\% in that category. An average of less than $1 \%$ of goals across all plans was devoted to post-implementation monitoring, with a high of $4 \%$ in California's plan. Given that most states are in the early stage of state adaptation planning, it is not surprising to observe the emphasis on planning and capacity-building activities.

TABLE 3. Plan goals by type (all goals).

\begin{tabular}{|c|c|c|c|c|c|c|c|c|}
\hline \multirow[b]{2}{*}{ State } & \multirow[b]{2}{*}{ Year } & \multirow[b]{2}{*}{ Total Goals } & \multicolumn{2}{|c|}{$\begin{array}{c}\text { Planning and } \\
\text { Capacity Building }\end{array}$} & \multicolumn{2}{|c|}{ Law and Policy } & \multicolumn{2}{|c|}{$\begin{array}{l}\text { Post-Implementation } \\
\text { Monitoring }\end{array}$} \\
\hline & & & \# & $\%$ & \# & $\%$ & $\#$ & $\%$ \\
\hline Alaska & 2010 & 158 & 124 & $78 \%$ & 34 & $22 \%$ & 0 & $0 \%$ \\
\hline California & 2009 & 345 & 199 & $58 \%$ & 131 & $38 \%$ & 15 & $4 \%$ \\
\hline Colorado & 2011 & 72 & 67 & $93 \%$ & 4 & $6 \%$ & 0 & $0 \%$ \\
\hline Connecticut & 2013 & 76 & 63 & $83 \%$ & 13 & $17 \%$ & 0 & $0 \%$ \\
\hline Florida & 2008 & 28 & 18 & $64 \%$ & 9 & $32 \%$ & 0 & $0 \%$ \\
\hline Maine & 2010 & 118 & 83 & $70 \%$ & 35 & $30 \%$ & 0 & $0 \%$ \\
\hline Maryland (I) & 2008 & 20 & 12 & $60 \%$ & 7 & $35 \%$ & 1 & $5 \%$ \\
\hline Maryland (II) & 2011 & 154 & 129 & $84 \%$ & 25 & $16 \%$ & 0 & $0 \%$ \\
\hline Massachusetts & 2011 & 373 & 312 & $84 \%$ & 59 & $16 \%$ & 2 & $1 \%$ \\
\hline New Hampshire & 2009 & 33 & 25 & $76 \%$ & 8 & $24 \%$ & 0 & $0 \%$ \\
\hline New York & 2010 & 121 & 78 & $64 \%$ & 43 & $36 \%$ & 0 & $0 \%$ \\
\hline Oregon & 2010 & 122 & 104 & $85 \%$ & 18 & $15 \%$ & 0 & $0 \%$ \\
\hline Pennsylvania & 2011 & 87 & 40 & $46 \%$ & 46 & $53 \%$ & 0 & $0 \%$ \\
\hline Virginia & 2008 & 43 & 31 & $72 \%$ & 12 & $28 \%$ & 0 & $0 \%$ \\
\hline Washington & 2012 & 287 & 222 & $77 \%$ & 62 & $22 \%$ & 3 & $1 \%$ \\
\hline Mean & & 135.8 & 100.5 & $73.0 \%$ & 33.7 & $25.9 \%$ & 1.4 & $0.5 \%$ \\
\hline
\end{tabular}




\section{Implementation progress}

States have made various degrees of progress in implementing those plans. Across plans, the average percentage of all goals that were assessed as "In Progress" is 53\%, with a low of $12 \%$ in Virginia and a high of $80 \%$ in Maryland's Phase I plan. The average number of goals assessed as "Completed" is $6 \%$. Table 4 displays the implementation progress made by each state. Table 4 also combines the In Progress and Completed goals to provide a more comprehensive measure of implementation progress.

TABLE 4. Plan implementation progress (all goals)

\begin{tabular}{|c|c|c|c|c|c|c|c|c|}
\hline \multirow[b]{2}{*}{ State } & \multirow[b]{2}{*}{ Year } & \multirow[b]{2}{*}{ Total Goals } & \multicolumn{2}{|c|}{ In Progress } & \multicolumn{2}{|c|}{ Completed } & \multicolumn{2}{|c|}{$\begin{array}{l}\text { In Progress and } \\
\text { Completed }\end{array}$} \\
\hline & & & $\#$ & $\%$ & $\#$ & $\%$ & $\#$ & $\%$ \\
\hline Alaska & 2010 & 158 & 52 & $33 \%$ & 1 & $1 \%$ & 53 & $34 \%$ \\
\hline California & 2009 & 345 & 251 & $73 \%$ & 48 & $14 \%$ & 299 & $87 \%$ \\
\hline Colorado & 2011 & 72 & 34 & $47 \%$ & 7 & $10 \%$ & 41 & $57 \%$ \\
\hline Connecticut & 2013 & 76 & 47 & $62 \%$ & 2 & $3 \%$ & 49 & $64 \%$ \\
\hline Florida & 2008 & 28 & 16 & $57 \%$ & 0 & $0 \%$ & 16 & $57 \%$ \\
\hline Maine & 2010 & 118 & 84 & $71 \%$ & 4 & $3 \%$ & 88 & $75 \%$ \\
\hline Maryland (I) & 2008 & 20 & 16 & $80 \%$ & 3 & $15 \%$ & 19 & $95 \%$ \\
\hline Maryland (II) & 2011 & 154 & 91 & $59 \%$ & 3 & $2 \%$ & 94 & $61 \%$ \\
\hline Massachusetts & 2011 & 373 & 191 & $51 \%$ & 24 & $6 \%$ & 215 & $58 \%$ \\
\hline New Hampshire & 2009 & 33 & 17 & $52 \%$ & 2 & $6 \%$ & 19 & $58 \%$ \\
\hline New York & 2010 & 121 & 63 & $52 \%$ & 17 & $14 \%$ & 80 & $66 \%$ \\
\hline Oregon & 2010 & 122 & 53 & $43 \%$ & 7 & $6 \%$ & 60 & $49 \%$ \\
\hline Pennsylvania & 2011 & 87 & 33 & $38 \%$ & 2 & $2 \%$ & 35 & $40 \%$ \\
\hline Virginia & 2008 & 43 & 5 & $12 \%$ & 2 & $5 \%$ & 7 & $16 \%$ \\
\hline Washington & 2012 & 287 & 165 & $57 \%$ & 12 & $4 \%$ & 177 & $62 \%$ \\
\hline Mean & & 135.8 & 74.5 & $52.5 \%$ & 8.9 & $6 \%$ & 83.5 & $59 \%$ \\
\hline
\end{tabular}

We also examine the progress states are making by sector (see Table 5). Across plans, the infrastructure sector has seen the most progress, with $10 \%$ of infrastructure goals either In Progress or Completed. The state that has made the most progress in any one sector is Maryland, with $40 \%$ of its 2008 goals in the Coasts and Oceans sector either In Progress or Completed.

We can also assess implementation progress by goal type. Across all plans, the goals related to Planning and Capacity Building have seen the most progress, with an average of $43 \%$ assessed as either In Progress or Completed. Goals in the Law and Policy category have been implemented at a lower rate, with an average of only $15 \%$ of these goals either In Progress or Completed across states. Maryland again 


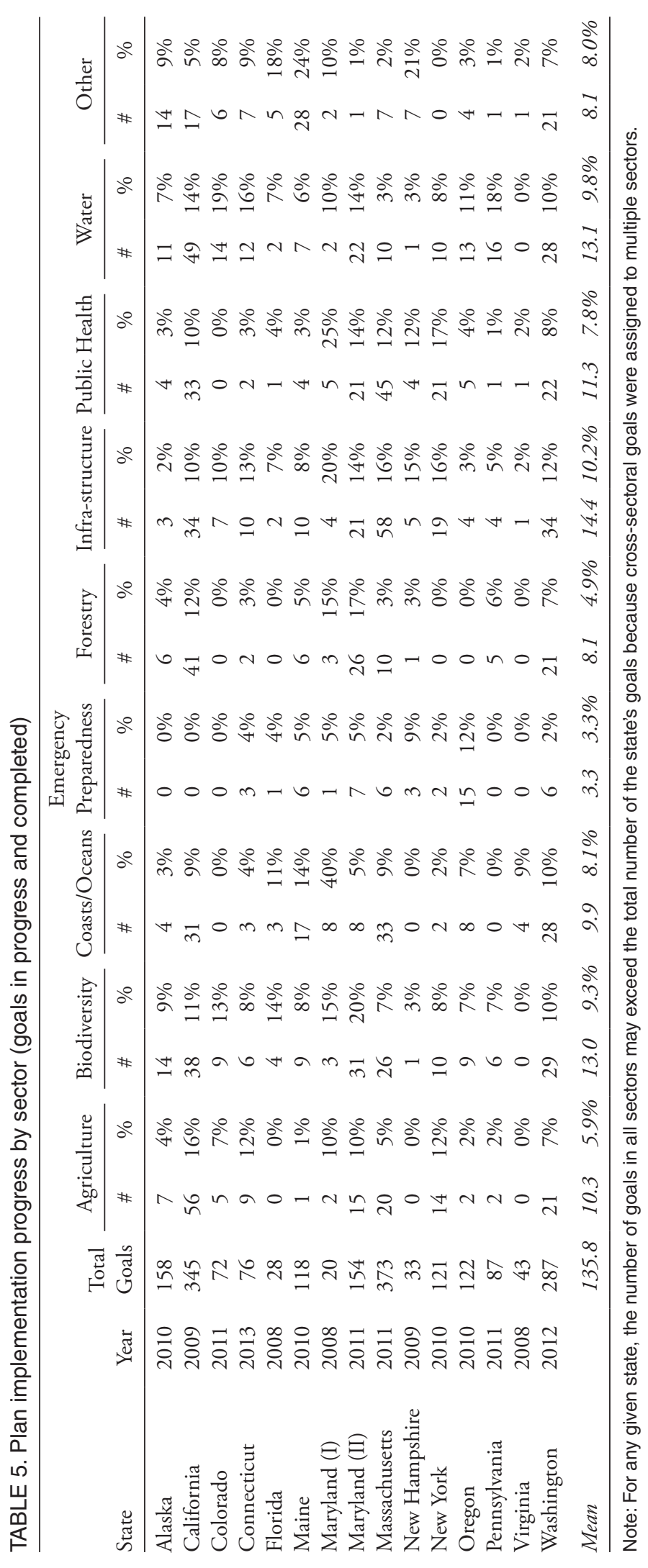


showed the most progress, with $60 \%$ of its Planning and Capacity Building goals from the 2008 plan assessed as either In Progress or Completed. In the Law and Policy category, California has achieved the highest rate of implementation, with $34 \%$ of goals in that category either In Progress or Completed.

TABLE 6. Plan implementation progress by goal type (goals in progress and completed).

\begin{tabular}{|c|c|c|c|c|c|c|c|c|}
\hline \multirow[b]{2}{*}{ State } & \multirow[b]{2}{*}{ Year } & \multirow[b]{2}{*}{ Total Goals } & \multicolumn{2}{|c|}{$\begin{array}{l}\text { Planning and } \\
\text { Capacity Building }\end{array}$} & \multicolumn{2}{|c|}{ Law and Policy } & \multicolumn{2}{|c|}{$\begin{array}{c}\text { Post-Implementation } \\
\text { Monitoring }\end{array}$} \\
\hline & & & \# & $\%$ & \# & $\%$ & $\#$ & $\%$ \\
\hline Alaska & 2010 & 158 & 45 & $28 \%$ & 8 & $5 \%$ & 0 & $0 \%$ \\
\hline California & 2009 & 345 & 177 & $51 \%$ & 116 & $34 \%$ & 6 & $2 \%$ \\
\hline Colorado & 2011 & 72 & 40 & $56 \%$ & 1 & $1 \%$ & 0 & $0 \%$ \\
\hline Connecticut & 2013 & 76 & 43 & $57 \%$ & 6 & $8 \%$ & 0 & $0 \%$ \\
\hline Florida & 2008 & 28 & 13 & $46 \%$ & 3 & $11 \%$ & 0 & $0 \%$ \\
\hline Maine & 2010 & 118 & 60 & $51 \%$ & 28 & $24 \%$ & 0 & $0 \%$ \\
\hline Maryland (I) & 2008 & 20 & 12 & $60 \%$ & 6 & $30 \%$ & 1 & $5 \%$ \\
\hline Maryland (II) & 2011 & 154 & 72 & $47 \%$ & 22 & $14 \%$ & 0 & $0 \%$ \\
\hline Massachusetts & 2011 & 373 & 177 & $47 \%$ & 36 & $10 \%$ & 2 & $1 \%$ \\
\hline New Hampshire & 2009 & 33 & 15 & $45 \%$ & 4 & $12 \%$ & 0 & $0 \%$ \\
\hline New York & 2010 & 121 & 50 & $41 \%$ & 30 & $25 \%$ & 0 & $0 \%$ \\
\hline Oregon & 2010 & 122 & 56 & $46 \%$ & 4 & $3 \%$ & 0 & $0 \%$ \\
\hline Pennsylvania & 2011 & 87 & 17 & $20 \%$ & 18 & $21 \%$ & 0 & $0 \%$ \\
\hline Virginia & 2008 & 43 & 2 & $5 \%$ & 3 & $7 \%$ & 0 & $0 \%$ \\
\hline Washington & 2012 & 287 & 136 & $47 \%$ & 40 & $14 \%$ & 1 & $0 \%$ \\
\hline Mean & & 135.8 & 61.0 & $43.2 \%$ & 21.7 & $14.5 \%$ & 0.7 & $0.5 \%$ \\
\hline
\end{tabular}

\section{Discussion}

While scholars have attempted to explain the adoption and content of state climate change mitigation and renewable energy policies (Huang et al. 2007; Matisoff 2008; Chandler 2009; Lyon and Yin 2010), little attention has been devoted to the adoption and content of state adaptation plans. A number of factors may influence a state's progress in implementing its plan. These include the impetus for the plan (e.g., executive order or legislative mandate), the number of goals in the plan, the level of political support, and the time elapsed since the publication of the plan. Other potential factors not captured in our data include the level of public and stakeholder engagement and existing local action on adaptation. Since the small number of plans limits our ability to use regression-based statistical analysis to formally test these hypotheses, we leave it to other researchers to assess the influence of these factors. Here we offer only a limited discussion of the potential influence of a few factors. 
One potential influence is the manner in which the plan development was initiated. Nine states initiated their planning process by executive action, and five states took direction from the legislature. Figure 1 plots the progress states are making implementing their plans (i.e., the percentage of goals either In progress or Completed out of the total number of goals in each plan) and the total number of goals in each plan. The data points corresponding to the individual state plans indicate whether the plans were initiated by the executive or legislature.

The average degree of progress in states with plans initiated by the executive is $57.9 \%$ (Standard Deviation $=0.22$ ). The average degree of progress in states with plans initiated by the legislature is $59.7 \%$ (Standard Deviation $=0.11$ ). This difference is not statistically significant. Similarly, the difference in the average total number of goals in plans initiated by the executive (109.6) and by the legislature (188.2) is also not statistically significant. It seems that the manner in which a plan is initiated does not explain either the scope of the plan or the progress the states are making in implementing that plan. However, the trend line included in Figure 1 provides some preliminary evidence of a relationship between implementation progress and the scope of a plan. The positive slope of the line indicates a positive

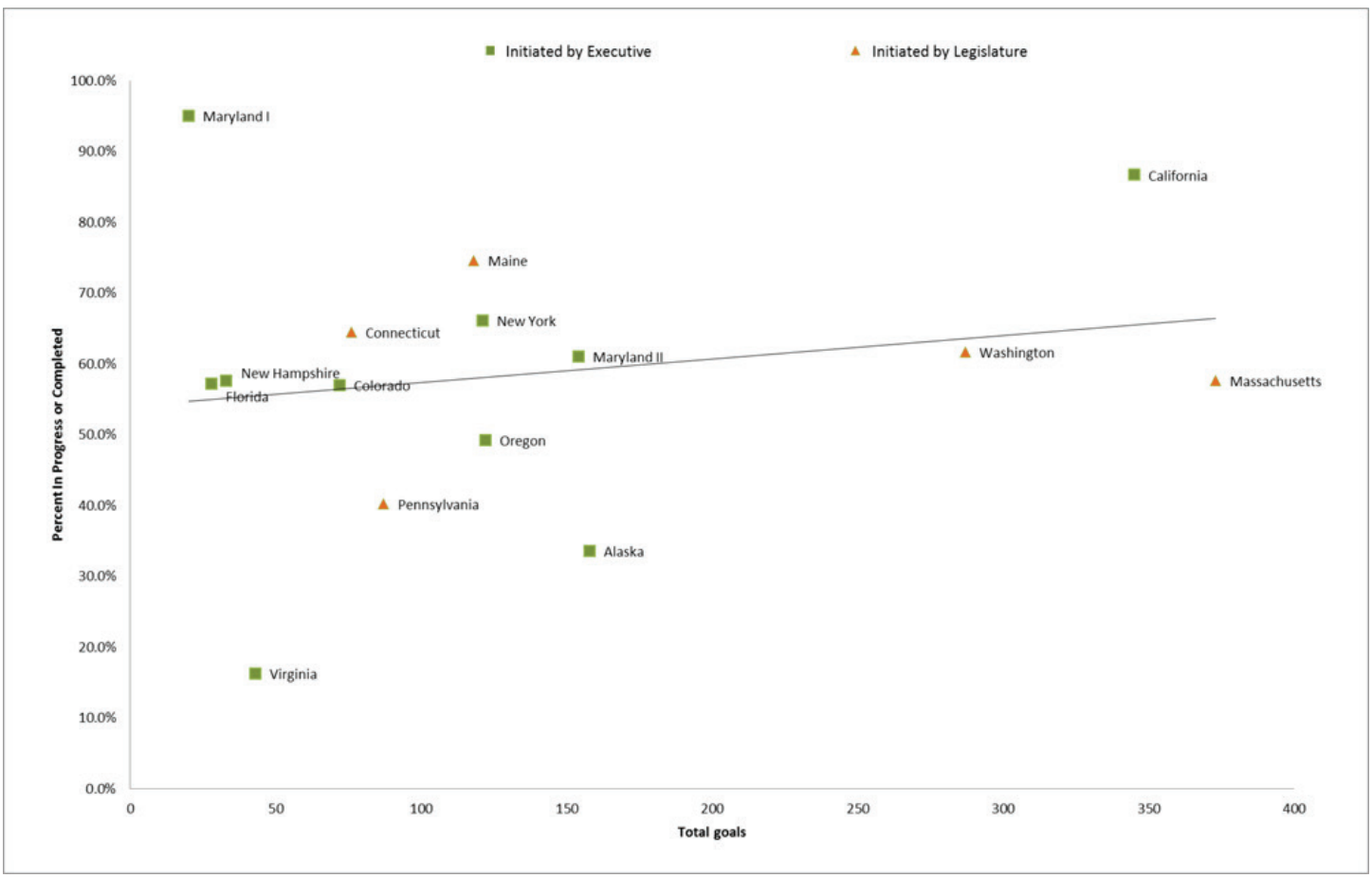

Figure 1. Plan impetus, total goals, and implementation progress. 
relationship between the total number of goals in a plan and the percentage of those goals characterized as either In Progress or Completed. The correlation coefficient of this relationship is $0.19(\mathrm{p}=0.49)$, a weak positive relationship. It may be that the most ambitious states, as indicated by the number of goals in their plans, are also the states making the most progress in implementation.

Another potential factor is the time elapsed since publication of the plan. It stands to reason that the more time a state has had to implement its plan, the more progress it will have made. A simple scatter plot illustrates this relationship see Figure 2). Examining this simple correlation reveals a positive relationship between implementation progress and the time elapsed since a plan was finalized. The slight upward slope of the trend line (from newest to oldest plans) indicates that more progress has been made on the recommendations in the oldest plans. The correlation coefficient of this relationship is $0.017(\mathrm{p}=0.95)$. While this is clearly a weak relationship, it is operating in the expected direction.

This analysis does not control for a number of potentially confounding factors, as the small number of cases hinders more sophisticated statistical analysis. Visual

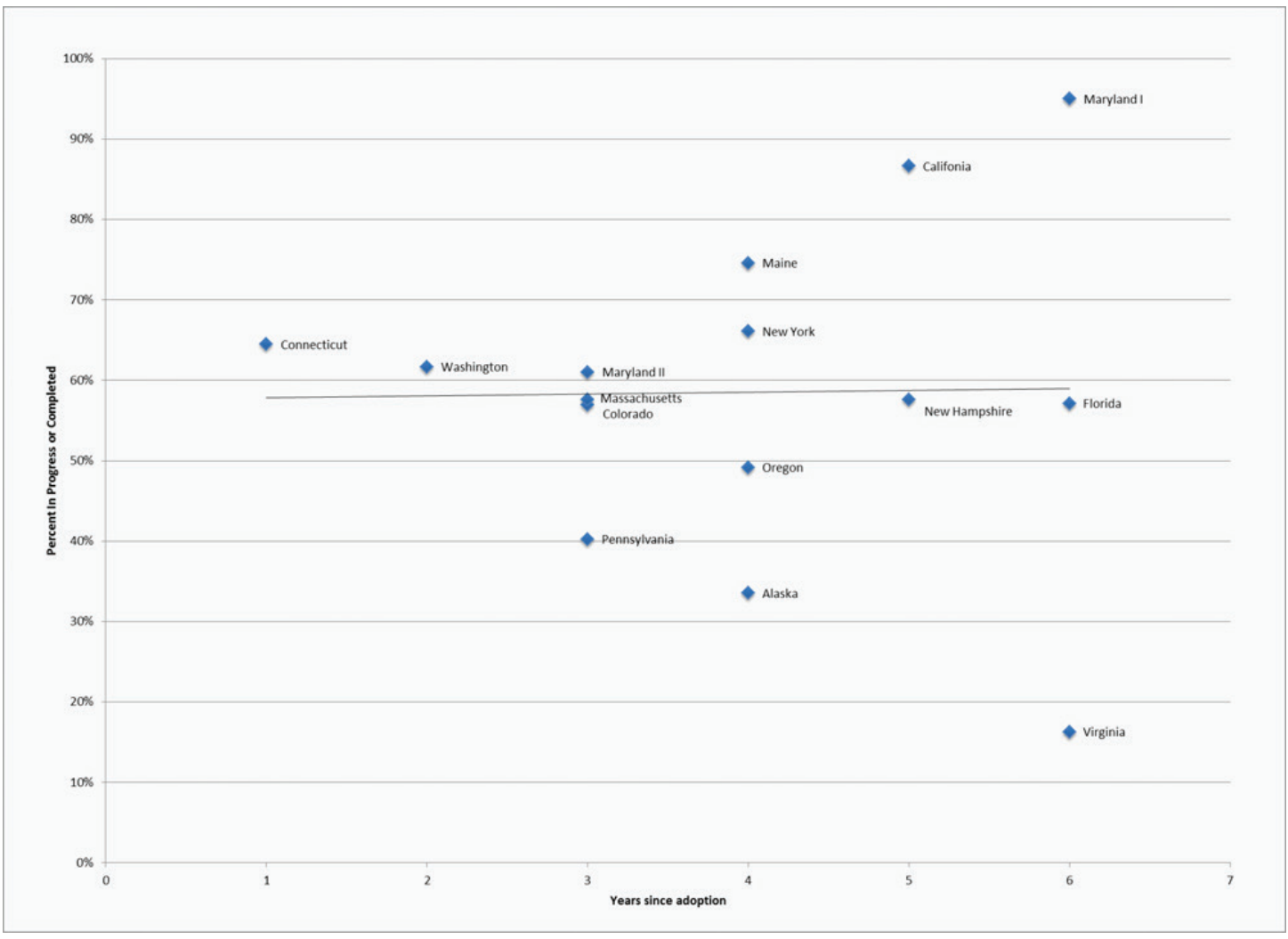

Figure 2. Plan implementation progress (goals in progress and completed), all states. 
inspection of the scatter plot in Figure 2 suggests the importance of one of those potentially confounding factors: the level of political support for a plan. Numerous scholars have explored the role partisanship plays in support for climate change policies, finding that Democratic constituencies are generally more supportive of public action on climate change (Dunlap and McCright 2008; Konisky et al. 2008; Zia and Todd 2010). Scholars have also studied states' adoption of renewable portfolio standards as a way to encourage the development of low-carbon energy generation. This line of research has found that political ideology is a significant factor in the adoption of RPS policies at the state level (Huang et al. 2007; Matisoff 2008; Chandler 2009; Lyon and Yin 2010). This literature suggests that the political dynamics of state governments may influence the policy outcomes achieved.

Five states, Alaska, Florida, Maine, Pennsylvania, and Virginia, experienced changes in their respective governor's offices after the adoption of their plans. In Alaska, Governor Parnell retired the climate cabinet created by his predecessor, Governor Palin (Goldenberg 2013). In Florida in 2011, the legislature passed and Governor Scott signed a bill to abolish the Florida Energy and Climate Commission (Florida 2011). In 2013, Maine's Governor LePage vetoed legislation that would have authorized the Department of Agriculture, Conservation, and Forestry to work with other state agencies to study the effects of climate change (Hoey 2013). In Pennsylvania, staffers at the Department of Conservation and Natural Resources were reportedly instructed by representatives of Governor Corbett to remove references to climate change from agency materials (Allegheny Front 2014). Finally, in Virginia, the Governor's Commission on Climate Change was discontinued by Governor McDonnell, who served from 2010 to 2014 (Springston 2014). These changes in political support may have slowed the implementation of plans in these states. In the five states highlighted above, the average amount of progress, as measured by the percentage of goals In Progress or Completed, was $44 \%$ (standard deviation $=0.20$ ). In the other nine states, the average amount of progress was $65 \%$ (standard deviation $=0.13)$. Although this 21-percentage-point difference in progress is statistically significant $(\mathrm{p}=0.04)$, a simple $\mathrm{t}$-test does not account for other potentially confounding factors.

Given this difference in implementation progress, the inclusion of these five states in Figure 2 may obscure the relationship between state progress and the time elapsed since the plans were finalized. Figure 3 presents the same data as in Figure 3 , with the removal of these five states from the analysis.

After we remove Alaska, Florida, Maine, Pennsylvania, and Virginia, the relationship between implementation progress and the time elapsed since the plan was 


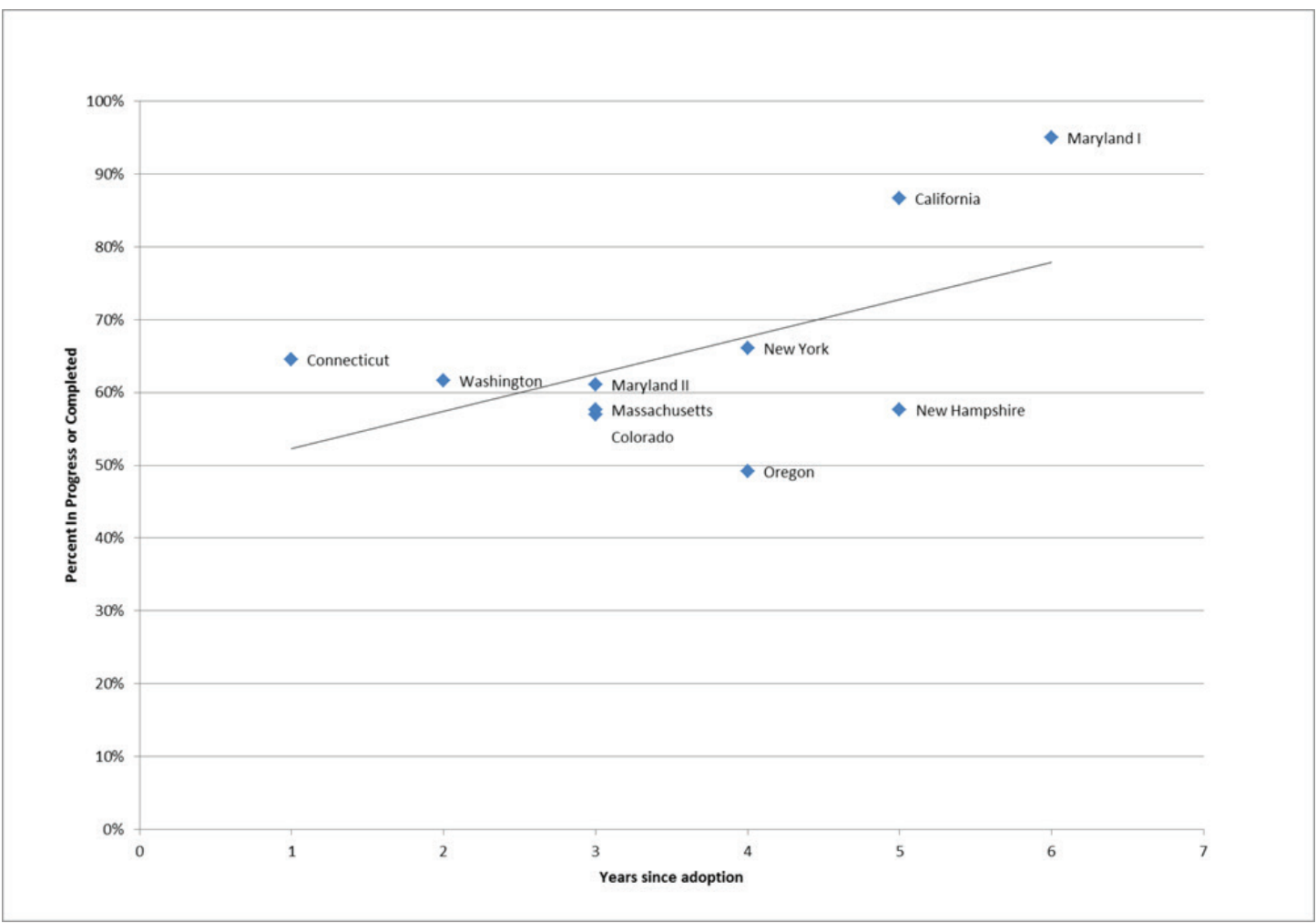

Figure 3. Plan implementation progress (goals in progress and completed), selected states.

finalized becomes more apparent. The correlation coefficient between these variables is $0.54(\mathrm{p}=0.10)$, indicating a moderately positive relationship between the age of the plan and progress in implementation. This provides at least some tentative support for the hypothesis that states achieve more progress over time. However, this apparent relationship is based on a simple correlation with a small number of cases, after we selected the states based on the dependent variable of political support, measured qualitatively. Clearly more research is needed into the factors that influence state progress in planning for climate impacts.

Practitioners experience the consequences for policy that elections can bring. In the arena of state adaptation policy, changes in administration can influence the level of priority attached to adaptation planning and implementation. Although there is some preliminary evidence that changes in the political environment may influence the progress states make in implementing their plans, we did find progress even in states with a change in administration. Anecdotally, we found that state agency staff in many of these states were committed to making progress and were interested in 
talking about the work they were doing. This suggests that these adaptation plans are somewhat durable across administrations and that setting goals can continue to influence agency activities even as political priorities change. In addition, state policy continues to evolve. In 2014, Governor McAuliffe of Virginia issued an executive order to reconstitute the state's climate change commission with a charge to review and update the work of the previous commission (Executive Order 19).

Variation among states in the development, content, and implementation of state adaptation plans is neither unexpected nor necessarily undesirable. The frequently cited role of the states as laboratories of democracy and policy innovation is predicated on their ability to respond to their particular mix of resources, perceived needs, political dynamics, and constituent preferences. The evidence from the experience of leading states in adaptation planning is that variation in state characteristics is associated with variation in the character of plans and the degree of implementation. It is possible that a more uniform planning approach across states may have resulted in a higher degree of implementation in some states. It is also possible, however, that this uniform approach may have inhibited some states from engaging in planning at all, ultimately leading to less action in these states.

The idiosyncratic approaches adopted by the leading states also can be viewed as an opportunity to experiment with multiple pathways for adaptation planning. One way of interpreting the early results of this experiment is that it has produced a set of models for the next round of state (and local and federal) adaptation planning. States are now able to examine these models and identify those that best fit their own mix of resources and needs. These models are available to the leading states as they update or adopt new plans, to the states with planning in progress, and to states that have not yet begun the planning process. Our interactions with state agency staff suggest a few practices that may facilitate implementation. First, states can set specific goals, identify agencies responsible for implementation, and set timelines to guide those agencies. Second, progress reports can be useful in tracking progress and ensuring accountability.

\section{Areas for further research}

Just as state adaptation planning is in its early stages, so is scholarly inquiry into it. Our research suggests a number of new directions. First, as states continue to implement existing plans, researchers need to continue tracking that implementation. The Georgetown Climate Center intends to regularly update its assessment with 
continued internal research, collaboration with state agency staff, and the input of practitioners and the public through an interactive web tool.

Second, researchers should track the implementation of new plans as they are adopted, either by states with plans, by states with planning in progress, or by states that have not yet begun the planning process. The Georgetown Climate Center intends to add new plans to its database and begin tracking their implementation in future phases of research. For example, in 2014 California released an update to its 2009 plan that includes new recommendations. We intend to track the implementation of this new plan and others as they are adopted.

Third, state adaptation planning is only one component of a national response to climate change. Planning is underway at the federal agency level and in many localities that have adopted local adaptation plans. The Georgetown Climate Center catalogues these local plans in its Adaptation Clearinghouse but has not yet begun tracking the implementation of these local adaptation plans. To gain a full understanding of our progress in preparing for climate impacts, we need research into the progress localities are making in implementing their adaptation plans. Research into local action may also include an assessment of the interactions between levels of government. In addition, a number of regional collaborations (e.g., the Southeast Florida Climate Compact, the Alliance of Regional Collaboratives for Climate Adaptation) complement state and local action; these warrant more attention from scholars.

Fourth, one clear potential driver of state action on adaptation is vulnerability to climate impacts. While it was beyond the scope of this article, other scholars could examine the influence of vulnerability to climate impacts on state or local adaptation action. Swart et al. (2009) argue that nation-states susceptible to extreme weather events and cognizant of the economic costs of inaction were driven to adopt national adaptation strategies. U.S. states or localities with perceived vulnerability to or recent experience with the impacts of climate change or natural disasters may also be more likely to adopt plans to reduce their vulnerability. Comparing states or localities that have adopted plans with states or localities that have not may be instructive.

Finally, there is a pressing need to understand the relationship between adaptation planning, implementation of that planning, and reduced vulnerability to climate impacts. The six-step approach to adaptation planning identified by the federal Interagency Climate Change Adaptation Task Force (ICCATF 2010) incorporates an evaluation step that feeds back into a new round of planning. Our research documents the progress states are making in implementing their adaptation 
plans, but we lack sufficient understanding of the efficacy of these actions. Thus, it is difficult to assess the progress states, localities, and federal agencies are making in actually reducing vulnerability to climate impacts. It is vitally important to collect baseline data, assess the efficacy of adaptation actions, and integrate this assessment back into the planning process.

\section{References}

Allegheny Front. 2014. "Corbett Officials Ordered DCNR to Drop Climate References from Website." September 19.

Arroyo, V., and T. Cruce. 2012. "State and Local Adaptation to Climate Change." In The Law of Adaptation to Climate Change, edited by Michael Gerrard and Katrina Kuh. American Bar Association.

Chandler, J. 2009. "Trendy Solutions: Why Do States Adopt Sustainable Energy Portfolio Standards?” Energy Policy 37:3274-3281.

Dunlap, R. and A. McCright. 2008. "Widening Gap: Republican and Democratic Views on Climate Change." Environment. Accessed December 11, 2011. http://www.environmentmagazine.org/Archives/Back\%20Issues/September-October\%202008/dunlap-full.html.

Florida. 2011. The Florida Senate: Interim Report 2012-112. Committee on Commerce and Tourism. October. http://www.Alsenate.gov/PublishedContent/Session/2012/ InterimReports $/ 2012-112 \mathrm{~cm}$.pdf.

Goldenberg, S. 2013. "From Palin to Parnell, the Great Alaska Climate Fail." Mother Jones. May 30. http://www.motherjones.com/environment/2013/05/palin-alaskas-politicans-struggleenvironment.

Hoey, D. 2013. "LePage Vetoes Climate Change Study." Portland Press-Herald. June 24. http:// www.pressherald.com/2013/06/24/lepage-vetoes-climate-change-study_2013-06-25/.

Huang, M., J. Alavalapati, D. R. Carter, and M. H. Langholtz. 2007. "Is the Choice of Renewable Portfolio Standards Random?" Energy Policy 35:5571-5575.

ICCATF (Interagency Climate Change Adaptation Task Force). 2010. Progress Report of the Interagency Climate Change Adaptation Task Force: Recommended Actions in Support of a National Climate Change Adaptation Strategy. White House Council on Environmental Quality. http://www.whitehouse.gov/sites/default/files/microsites/ceq/Interagency-Climate-ChangeAdaptation-Progress-Report.pdf.

IPCC (Intergovernmental Panel on Climate Change). 2007. "Glossary." In Climate Change 2007: Working Group II: Impacts, Adaptation and Vulnerability, Contribution of Working Group II to the Fourth Assessment Report of the Intergovernmental Panel on Climate Change, edited by M.L. Parry, O.F. Canziani, J.P. Palutikof, P.J. van der Linden and C.E. Hanson. Cambridge University Press, Cambridge, UK.

Konisky, D. M., J. Milyo, and L. E. Richardson Jr. 2008. "Environmental Policy Attitudes: Issues, Geographical Scale, and Political Trust.” Social Science Quarterly. 89 (5): 1066-1085.

Lyon, T., and H. Yin. 2010. "Why Do States Adopt Renewable Portfolio Standards? An Empirical Investigation." The Energy Journal. 31 (3): 131-156. 
Matisoff, D. 2008. "The Adoption of State Climate Change Policies and Renewable Policies and Renewable Portfolio Standards: Regional Diffusion or Internal Determinants?” Review of Policy Research 25 (6): 527-546.

Rabe, B. 2004. Statehouse and Greenhouse: The Emerging Politics of American Climate Change Policy. Washington, D.C.: Brookings Institution Press.

Selin, H., and S. VanDeveer. 2007. "Political Science and Prediction: What's Next for U.S. Climate Change Policy?" Review of Policy Research 24:1.

Springston, R. 2014. "McAuliffe Reinstates Climate Commission." Richmond Times-Dispatch. July 1. http://www.timesdispatch.com/news/state-regional/mcauliffe-reinstates-climatecommission/article_5ef2f272-0144-11 e4-9a90-0017a43b2370.html.

Swart, Rob, Robbert Biesbroek, Svend Binnerup, Timothy R. Carter, Caroline Cowan, Thomas Henrichs, Sophie Loquen, Hanna Mel, Michael Morecroft, Mortiz Reese, and Daniela Rey. 2009. Europe Adapts to Climate Change: Comparing National Adaptation Strategies. Helsinki: Partnership for European Environmental Research. Accessed December 9, 2011. http://www. peer.eu/fileadmin/user_upload/publications/PEER_Report1.pdf.

Thomson, V., and V. Arroyo. 2011. "Upside-Down Cooperative Federalism: Climate Change Policymaking and the States." Virginia Environmental Law Journal 29 (1): 1-62.

Wheeler, S. 2008. "State and Municipal Climate Change Plans: The First Generation." Journal of the American Planning Association. 74 (4): 481-496.

Zia, A., and A. Todd. 2010. "Science: How to Improve Communication across Ideological Divides? Evaluating the Effects of Ideology on Public Understanding of Climate Change." Public Understanding of Science 19:743.

\section{Acknowledgements}

The Georgetown Climate Center's State Adaptation Progress Tracker, which tracks the progress of states in implementing their adaptation plans, is supported by the MacArthur Foundation.

\section{Appendix: Methodology}

Updated September 10, 2014

1. Identify states and plans

- Identify states with statewide climate change adaptation plans or adaptation sections of climate action plans

- Categories and criteria

- State-led, finalized plans

- Creation of an adaptation plan was called for by executive or legislative action (e.g., executive order, legislation) or as part of a climate action plan 
- Development of the plan was supported by the state government (e.g., funding was provided by the state government or state agencies, or state agency staff participated in the process)

- Adaptation plan has been completed

- Plan is comprehensive (e.g., includes multiple sectors)

- Plan includes specific goals for adaptation action

- Planning in progress

- State-led and/or supported (see above) but plan is not complete

- Plan was led and/or supported by non-state organization(s) (e.g., academic institutions, NGOs)

- Plan is not comprehensive (e.g., it only covers a single sector)

- No plans

- States without either of the above

- Research into implementation status proceeds with state-led, finalized plans

- Collect publicly available electronic version of plan

- Record plan title and publication date

2. Document goals

- Review plan

- Record discrete, assessable goals

- Follow plan organizational scheme when possible

- If plan is not organized into discrete, assessable goals, divide relevant text into discrete, assessable goals

- Record the number of the page on which the goal can be found

- Assign each goal a unique identifier, usually consisting of a reference to the chapter or sector and the numeric order of the goal in that section

- When available, record the agency responsible for implementation

3. Characterize goals

- For each goal, assign one of three categories (i.e., Planning and Capacity Building; Law and Policy; Post-Implementation Monitoring)

- Definitions

- Planning and Capacity Building

- This category captures activities that provide information, express aspirations, encourage collaboration, provide technical assistance, assess vulnerability, articulate plans, etc.

- These activities include coordination and collaboration activities, vulnerability assessments, planning processes, development of tools, education, 
data collection, research, monitoring to establish baselines, setting milestones, conduction outreach, providing technical assistance, etc.

- Example: "Conduct predictive modeling and risk assessment for invasive species and pathogens that may be moving into the state" (PA, NRPW3.1)

- Law and Policy

- This category captures activities that create new or change existing laws; create new programs; provide new, additional, or redirected funding; create new or reform existing regulations; or otherwise compel action on the part of state agencies or private actors

- These activities include new or revised regulations, codes, binding guidance, new legislation, new funding sources, guidelines, and requirements, zoning changes, new programs, new design standards, etc.

- Example: "Revise storm water regulations to accommodate increases in precipitation and run-off” (PA, NR-W2.2)

- Post-Implementation Monitoring

- This category captures activities that monitor the impact of adaptation actions after they have been implemented

- These activities include monitoring of the effectiveness of plan components after implementation

- Example: "More intense inspection of transportation infrastructure after high impact events in areas that are subject to erosion" (PA, ITransportation3)

- Use language of goal to guide assignment

- When distinction is unclear from initial review, goals in question are referred to state contacts for aid in classification

- For each goal, assign one of nine sectors (i.e., Agriculture, Biodiversity, Coasts/ Oceans, Forestry, Emergency Preparedness, Public Health, Infrastructure, Water, Other)

- Use plan organization/characterization to guide assignment

- If plan organization is not explicit, use following guidelines:

- Water includes human use of water (e.g., water supply, drinking water)

- Biodiversity includes species health, habitat preservation, etc.

- Infrastructure includes both energy and transportation-related goals

- Assign multiple sectors if appropriate 
4. Assess state progress implementing goals

- For each goal, search publicly available information sources (e.g., progress reports, state agency websites) for evidence of implementation of the goal

- Search the following resources as available:

- State-, NGO-, and academic-produced progress reports

- State agency websites

- General search of publicly available electronic sources (i.e., Google search of key words from goal)

- For every goal, search all three categories of resources

- Count only evidence occurring after the plan's publication

- Count as evidence action directly related to plan goal even if plan is not cited explicitly

- Count as evidence action directly related to plan goal even if climate change or climate change adaptation is not cited explicitly

- For each goal, assign one of three categories (i.e., No Evidence of Progress, In Progress, Completed)

- Definitions

- No Evidence of Progress: After conducting search of resources, no evidence of implementation is found

- In Progress: After conducting search of resources, evidence is found that indicates progress toward completing the goal

- Completed: After conducting search of resources, evidence is found that the goal has been completed

- When appropriate, provide narrative description of progress and rationale for judgment

- Record link to source of evidence

- For completed goals, provide link to resources in Adaptation Clearinghouse that document completion

5. Pre-publication state outreach

- After completing assessment, solicit feedback from relevant states using one of the following processes, as appropriate

- Provide state officials with research and ask for additional evidence of progress

- Provide state officials with summary of assessment and ask for additional evidence of progress

- Provide relevant state agency officials with a sector-specific portion of the tracking spreadsheet or summary of assessment and ask for additional evidence of progress 
- Method of soliciting state input depends on the particular details of the state's planning process and organization

- Ask states to provide evidence of progress (e.g., link to website, document) before changing the initial assessment of progress

- Revise initial assessment as appropriate based on state feedback

6. Post-publication revision

- After initial publication, states and others will have the opportunity to continue to provide updates and feedback

- Button on website allows states and others to provide ongoing updates of progress

- Ask states and others to provide evidence of progress (e.g., link to website, document) before changing the initial assessment of progress

- Revise assessment as appropriate based on received information and updates

7. Periodic updates

- Assessment will be updated by GCC for two years after publication; once every six months, or more frequently as needed

- Update process will follow steps described in section 4 above 